\title{
An Investigation into the Impact of Reaction Temperature on Various Parameters during Torrefaction of Sugarcane Bagasse Relevant to Gasification
}

\author{
Anthony Anukam, ${ }^{1,2}$ Sampson Mamphweli, ${ }^{1}$ Prashant Reddy, ${ }^{3}$ \\ Omobola Okoh, ${ }^{2}$ and Edson Meyer ${ }^{1}$ \\ ${ }^{1}$ Fort Hare Institute of Technology, University of Fort Hare, Private Bag X1314, Alice 5700, South Africa \\ ${ }^{2}$ Department of Chemistry, University of Fort Hare, Private Bag X1314, Alice 5700, South Africa \\ ${ }^{3}$ Department of Chemistry, Durban University of Technology, P.O. Box 1334, Durban 4000, South Africa
}

Correspondence should be addressed to Anthony Anukam; aanukam@ufh.ac.za

Received 14 September 2015; Accepted 25 November 2015

Academic Editor: Mohsen Farahat

Copyright (C) 2015 Anthony Anukam et al. This is an open access article distributed under the Creative Commons Attribution License, which permits unrestricted use, distribution, and reproduction in any medium, provided the original work is properly cited.

\begin{abstract}
Torrefaction of sugarcane bagasse was conducted in an electric muffle furnace at 200, 250, and $300^{\circ} \mathrm{C}$ in order to establish the impact of heat treatment temperature on various parameters and as a method to improve sugarcane bagasse characteristics for the purpose of gasification. The results show that weight loss of bagasse reduced as temperature of torrefaction increased due to excessive devolatilization. A reduced moisture and volatile matter content as well as improved calorific value were also achieved with increasing temperature of torrefaction. The torrefaction progress was again followed by elemental analysis of the material which showed the presence of $\mathrm{C}, \mathrm{H}$, and $\mathrm{O}$ in varying proportions depending on torrefaction temperature. The decrease in the weight percentages of $\mathrm{O}_{2}$ and $\mathrm{H}_{2}$ as torrefaction reaction temperature increased resulted in the accumulation of $\mathrm{C}$ in the solid product. The thermogravimetric analysis conducted established the maximum reactivity temperature of the torrefied material and revealed that the degradation of torrefied sugarcane bagasse was accelerated by thermal treatment of the material prior to analysis. Finally, the study established that torrefaction at $300^{\circ} \mathrm{C}$ led to a much more degraded material compared to the lower torrefaction reaction temperatures of 200 and $250^{\circ} \mathrm{C}$, respectively.
\end{abstract}

\section{Introduction}

The effect of the application of fossil fuels for energy production on global environment has renewed the interest in the use of alternative energy sources because fossil fuels contain carbon that has been out of the carbon cycle for a long time, and therefore their combustion disturbs the carbon in the atmosphere. Biomass happens to be the only renewable source of carbon, a chemical element essential for the manufacture of chemicals and materials. There are two major routes to bioenergy production, which are thermochemical (combustion, gasification, and pyrolysis) and biological (anaerobic digestion and fermentation) processes. These processes can provide a near-term solution to the problem of energy $[1,2]$. However, the low-quality properties of biomass are often revealed when a direct comparison is made with coal which is still the dominant solid fuel in heat and electricity generation in South Africa. The use of raw biomass for energy production on a commercial scale has seriously been challenged by high cost of biomass storage, susceptibility to microbial degradation due to its hygroscopic nature, heterogeneous nature, and appreciable amount of $\mathrm{O}_{2}$ relative to $\mathrm{C}$ that makes it thermally unstable and produces reasonable quantities of tar that can be problematic in conventional thermal conversion systems such as the gasification systems $[3,4]$. Other issues include its low energy and bulk densities as well as its high moisture content, which requires drying before conversion including the high concentrations of alkali and alkaline earth metal elements. These features result in many issues such as the high energy required for 
size reduction and feeding challenges due to poor flowability as well as lower heat to mass transfer rates during thermal conversion of the biomass including the formation of alkali sulfates and silicates, which stick on the surface of the combustion chamber affecting the rate of heat transfer [5]. Taking these challenges into cognizance, bioenergy production involving thermal conversion of biomass can incorporate torrefaction as a preprocessing method in the production chain to overcome the aforementioned issues. Because gasification process efficiency, among other factors, depends on feedstock properties, biomass properties are improved upon torrefaction for better thermal conversion of the material [6]. A mass loss of about $40 \%$ is achieved during torrefaction with an energy loss in the range of 5 and $10 \%[7,8]$. The energy and bulk densities of the biomass are also increased; moisture is expelled after torrefaction leading to ease of feedstock ignition during thermal conversion $[7,9]$. However, the major components of biomass are cellulose, hemicellulose, and lignin, and the thermal decomposition temperatures of these components are quite different as cellulose degrades between 250 and $500^{\circ} \mathrm{C}$, while hemicellulose decomposition is in the range of 150 and $350^{\circ} \mathrm{C}$, with lignin degrading over a wider temperature range from 150 to $900^{\circ} \mathrm{C}[10,11]$.

Gasification is a thermochemical process that relies on the use of molecular dissociation to convert energy stored in any given feedstock into usable energy, which is in the form of a mixture of gases collectively known as syngas, while torrefaction is a thermal treatment process carried out at relatively mild temperatures (between 200 and $300^{\circ} \mathrm{C}$ ) in a chemically inactive environment to improve the properties of biomass relevant to gasification $[6,12]$. The characteristics and percentage distribution of the end products obtained after torrefaction strongly depend on process conditions such as temperature, time of torrefaction, and type of feedstock as well as the type of torrefaction equipment employed; those of gasification are also heavily dependent upon the same type of conditions including process reaction conditions $[13,14]$. The following major reactions take place during gasification of biomass and are the major determinants of product gas composition and yield $[15,16]$ :

Drying zone:

$$
\mathrm{H}_{2} \mathrm{O}_{(\mathrm{l})} \longrightarrow \mathrm{H}_{2} \mathrm{O}_{(\mathrm{g})} ; \quad \mathrm{q} \Delta \mathrm{H}^{0}=+40.7 \mathrm{~kJ} \mathrm{~mol}^{-1}
$$

Devolatilization zone:

$$
\mathrm{CH}_{x} \mathrm{O}_{y} \mathrm{~N}_{z} \longrightarrow \text { Volatiles + char }
$$

Oxidation zone:

$$
\begin{aligned}
\mathrm{C}+0.5 \mathrm{O}_{2} & \longrightarrow \mathrm{CO} ; \quad \Delta \mathrm{H}^{0}=-268 \mathrm{~kJ} \mathrm{~mol}^{-1} \\
\mathrm{C}+\mathrm{O}_{2} & \longrightarrow \mathrm{CO}_{2} ; \quad \Delta \mathrm{H}^{0}=-406 \mathrm{~kJ} \mathrm{~mol}^{-1}
\end{aligned}
$$

Reduction zone (water gas reaction):

$$
\mathrm{C}+\mathrm{H}_{2} \mathrm{O} \longrightarrow \mathrm{CO}+\mathrm{H}_{2} ; \quad \Delta \mathrm{H}^{0}=+131.4 \mathrm{~kJ} \mathrm{~mol}^{-1}
$$

Boudouard reaction:

$$
\mathrm{C}+\mathrm{CO}_{2} \longrightarrow 2 \mathrm{CO} ; \quad \Delta \mathrm{H}^{0}=+172.6 \mathrm{~kJ} \mathrm{~mol}^{-1}
$$

Water gas shift reaction:

$$
\mathrm{CO}+\mathrm{H}_{2} \mathrm{O} \longleftrightarrow \mathrm{CO}_{2}+\mathrm{H}_{2} ; \quad \Delta \mathrm{H}^{0}=-42 \mathrm{~kJ} \mathrm{~mol}^{-1}
$$

Methanation reaction:

$$
\mathrm{C}+2 \mathrm{H}_{2} \longleftrightarrow \mathrm{CH}_{4} ; \quad \Delta \mathrm{H}^{0}=-75 \mathrm{~kJ} \mathrm{~mol}^{-1}
$$

These gasification reactions occur simultaneously and their equilibrium positions are equally affected by temperature [17]. In comparison to other thermochemical conversion processes, however, the gasification technology is more efficient and more environmentally friendly in terms of performance and considered an important route for biomass conversion or utilization; as such, feedstocks for conversion in gasification systems need to have properties similar to high-value coal, for optimum efficiency to be achieved $[6,18]$.

There have been quite a number of research studies performed on biomass torrefaction for different purposes including the purpose of gasification; however there still remains inadequate information on the gasification performances of biomass torrefied at various reaction temperatures. The torrefaction of rice straw and rape stalk was conducted by Deng et al. [19] at 200,250 , and $300^{\circ} \mathrm{C}$ who compared the results obtained with those of their parent materials and found that the conversion rates of the raw materials were much higher than those of their torrefied materials owing to higher content of volatile matter in the raw materials, while Pimchuai et al. [20] investigated the influence of torrefaction temperature on the properties of certain biomass materials which included sugarcane bagasse. They concluded that increasing energy density of the torrefied materials was affected more by temperature than any other process condition. A close conclusion was reached by Bridgeman et al. [18], who studied the combustion performances of raw and torrefied reed canary grass, wheat straw, and willow. The effect of torrefaction on the properties of miscanthus that are pertinent to gasification was undertaken by Xue et al. [6] at various torrefaction temperatures. They found that the torrefied material showed improved properties that had positive impact on gasification reactivity. Therefore, the aim of this study is to evaluate the influence of torrefaction reaction temperature on various parameters during torrefaction of sugarcane bagasse with emphasis on the transformed properties of the material that are pertinent to gasification.

\section{Experimental}

2.1. Materials. The biomass used in this study was sugarcane bagasse because of its availability in excess of its usage. It was obtained from a local sugarcane mill in KwaZulu-Natal, South Africa. The bagasse was received with about $40 \%$ moisture and was dried outdoors at ca. $32^{\circ} \mathrm{C}$ for 7 days before being pulverized to fine powder. 
2.2. Procedure for Sugarcane Bagasse Torrefaction. Torrefaction of sugarcane bagasse was conducted at 200, 250, and $300^{\circ} \mathrm{C}$ in an electric enfolded furnace connected to a $\mathrm{N}_{2}$ gas dispenser system to ensure an inert atmosphere and a condenser for gas collection. In addition to the muffle furnace, the $\mathrm{N}_{2}$ gas supply system, and the condenser, the torrefaction setup also consisted of a tubular reactor made of stainless steel, which is designed to fit inside of the furnace. $15 \mathrm{~g}$ of sugarcane bagasse was weighed and placed in a sample holder embedded in the tubular reactor. The reactor containing the sample was then placed inside the furnace which had been preheated to a set temperature. The experiment was repeated three times at different aforementioned torrefaction temperatures under the same experimental conditions. As soon as the reaction temperature reached the set temperatures for each of the three experimental runs, the experiment was stopped. This was counted from the time the experiment began at room temperature to the time the torrefaction reaction temperature reached 200,250 , and $300^{\circ} \mathrm{C}$, respectively. A residence time of 5 min was maintained in the furnace for each reaction temperature to allow the reaction run to completion. The residence time was made relatively short to avoid severe sample decomposition while still in the furnace. During the experiment, condensable and noncondensable as well as solid, liquid, and gaseous products were produced and were all collected and preserved for analysis.

The mass and energy yields of the torrefied bagasse were determined at different torrefaction temperatures and were evaluated on a dry and ash-free basis (daf) according to (9) and (10), respectively [22]. One has

$$
\begin{aligned}
\text { Mass yield (wt.\%) } & =\frac{M_{\text {torrefied }}}{M_{\text {untorrefied }}} \times 100, \\
\text { Energy yield } & =\frac{\text { Mass yield } \times \mathrm{CV}_{\text {torrefied }}}{\mathrm{CV}_{\text {untorrefied }}} \times 100,
\end{aligned}
$$

where $M$ is the mass and $\mathrm{CV}$ is the calorific value of torrefied and raw bagasse, respectively.

The yields of solid, liquid, and gaseous products formed during the process were determined according to (11), (12), and (13), respectively [23, 24]. One has the following:

$$
\text { Solid yield }(\%)=\frac{m_{2}(\mathrm{~g})}{m_{1}(\mathrm{~g})} \times 100 \%,
$$

where $m_{1}$ and $m_{2}$ are the weight of bagasse before and after torrefaction. One has

$$
\text { Liquid yield }(\%)=\frac{w_{2}(\mathrm{~g})}{w_{1}(\mathrm{~g})} \times 100 \%,
$$

where $w_{1}$ and $w_{2}$ are the mass loss of raw bagasse and mass of liquid generated during torrefaction, respectively. One has

$$
\text { Gaseous yield }(\%)=\frac{a_{2}(\mathrm{~g})}{a_{1}(\mathrm{~g})} \times 100 \% \text {, }
$$

where $a_{1}$ and $a_{2}$ are weight loss of raw bagasse and weight of gaseous products formed during torrefaction.
The composition of the gaseous products formed from sugarcane bagasse torrefaction at various temperatures was determined by a Perkin Elmer Auto-System XL gas chromatographic (GC) instrument that used Argon as a carrier gas at a flow rate of $35 \mathrm{~mL} / \mathrm{min}$.

2.3. Material Analysis. The analysis of the torrefied material incorporated proximate and ultimate analyses as well as calorific values including morphology and thermal behavior of bagasse obtained at different torrefaction temperatures. The information for proximate analysis was evaluated from the TGA plot in Figure 3(a), while that of ultimate analysis was obtained from a ThermoQuest CHNS elemental analyzer, which gave the concentrations, in percentage of the individual elements contained in the torrefied material. The calorific value of torrefied bagasse was measured by an oxygen bomb calorimeter that had its vessel pressurised at $3000 \mathrm{kPa}$ before measurements were taken. These analyses were undertaken for the different torrefaction temperatures and results presented in Section 3 of this paper.

2.3.1. Thermogravimetric Analysis. The thermogravimetric analyzer (TGA), a Perkin Elmer TGA 7, was used to study the thermal behavior of bagasse torrefied at different temperatures. This analysis was necessary to determine the thermal stability as well as establish the parameters that would influence the thermal conversion of the material. The sample was heated in the instrument over a wide temperature range, starting from room temperature to $\mathrm{ca} .1000^{\circ} \mathrm{C}$ under an inert atmosphere of $\mathrm{N}_{2}$. The thermogravimetric analyzer is a high temperature instrument where ordinarily nonreactive materials become reactive. So $\mathrm{N}_{2}$ was used to ensure a chemically inactive environment because of its relatively nonreactive nature with many materials. This property of $\mathrm{N}_{2}$ has been attributed to the strong bonds that exist within its structure [24]. $\mathrm{N}_{2}$ condenses and freezes at a particular temperature, and because of these properties, it is used to prevent the instrument from burning. Heating was undertaken at a rate of $10^{\circ} \mathrm{C} / \mathrm{min}$ and the weight loss of the material obtained as a function of temperature and time in order to establish the thermal decomposition temperatures of the components of the material, and the time decomposition occurred. This analysis sufficiently describes the conditions existing in a typical gasification system since it involves a high temperature instrument.

The data from TGA was collected by a computer and the weight loss process of the samples plotted as a function of time and temperature. Proximate analysis data was determined from the weight loss process of the samples after thermogravimetric analysis in accordance with the equation parameters presented in Table 1.

2.3.2. SEM/EDX Analyses. The morphological characterization of torrefied bagasse was conducted under a JEOL (JSM-6390LV) model SEM analyzer fitted with an energydispersive X-ray (EDX) analyzer used to quantify the inorganic components of the sample. Both the SEM and EDX analyses were determined at a glance since both instruments 
TABLE 1: Method equation parameters for proximate analysis determination from TGA curve [21].

\begin{tabular}{lc}
\hline Equation name & Parameters \\
\hline Moisture content & $(([$ Initial Mass $]-[$ Moisture Mass $]) /[$ Initial Mass $]) * 100$ \\
Volatile matter content & $(([$ Moisture Mass $]-[$ Volatile Mass $]) /[$ Initial Mass $]) * 100$ \\
Ash & $([$ Ash Mass $] /[$ Initial Mass $]) * 100$ \\
Fixed carbon & $100-([$ Moisture $]+[$ Volatile $]+[$ Ash $])$ \\
\hline
\end{tabular}

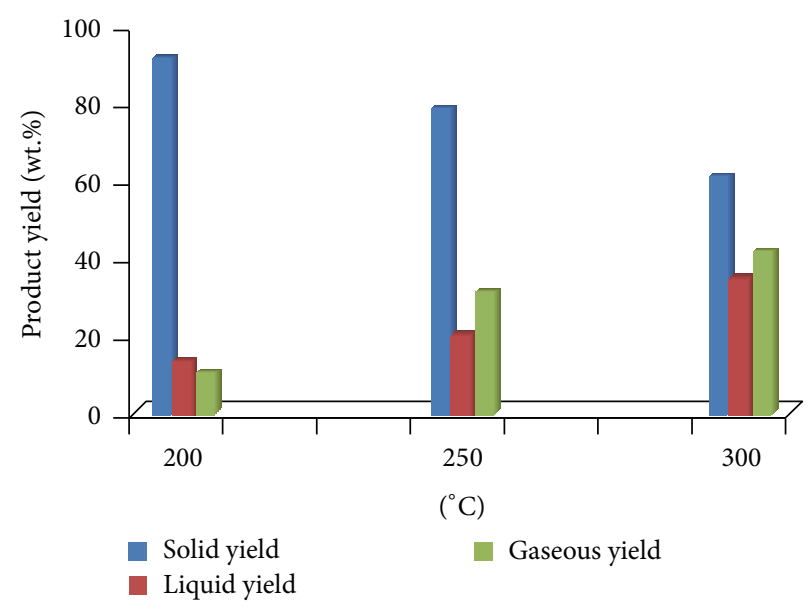

(a)

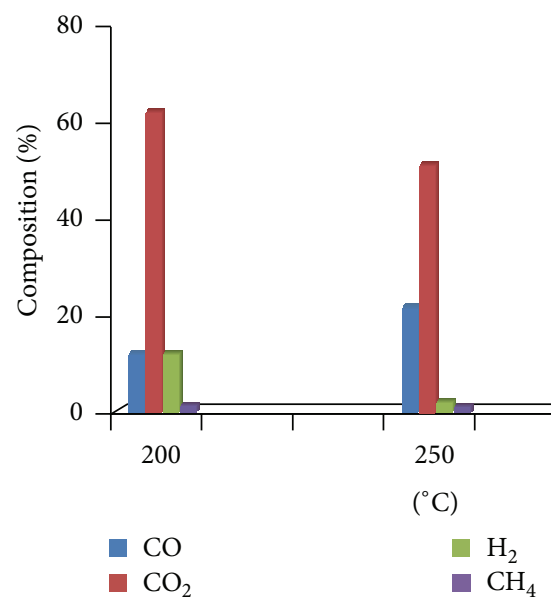

(b)

FIGURE 1: Impact of torrefaction on (a) the yield of products and (b) percentage composition of gaseous products formed from sugarcane bagasse torrefied at different temperatures.

are hyphenated. For the EDX analysis, elements present in the sample absorb the X-ray beam, resulting in movement of electrons from a ground state, causing dislocation of the electrons and thereby creating a hole that is filled by electrons from other higher energy states. This creates a difference in energy which results in peak formation.

\section{Results and Discussion}

3.1. Products of Sugarcane Bagasse Torrefaction. The reaction products of torrefaction and their yield are solidly dependent upon the conditions of torrefaction such as temperature and time as well as the characteristics of the material [25]. Figures 1(a) and 1(b) show the impact of torrefaction on the yield of products as well as on the percentage composition of the gases formed from sugarcane bagasse torrefaction at different temperatures.

From Figure 1(a), it could be easily noticed that torrefaction at $200^{\circ} \mathrm{C}$ gave a higher solid yield and a lower liquid and gaseous yield in comparison to torrefaction at 250 and $300^{\circ} \mathrm{C}$, respectively. This is because of the lower temperature $\left(200^{\circ} \mathrm{C}\right)$ at which torrefaction began. The degree of decomposition and the yield of solids during torrefaction of biomass depend on the temperature of torrefaction $[9,11$, 25]. As temperature increases, the yield of solid decreases due to extensive decomposition of the major components (cellulose, hemicellulose, and lignin) of the material $[18,26]$. It is also quite clear from Figure 1(a) that the yield of solid decreased as torrefaction reaction temperature increased due to increasing thermal decomposition of the material. This observation is attributed to the devolatilization of the major components of the material as torrefaction temperature increased, thereby affecting the yield of the solid product (the torrefied material). These components are each characterized by their own decomposition temperature, which also impacts on the yield of the solid product obtained after torrefaction $[25,27]$. Figure 1(b) on the other hand shows that the permanent gaseous products formed from bagasse torrefaction at different temperatures mainly contain $\mathrm{CO}$ and $\mathrm{CO}_{2}$, alongside fairly trace quantities of $\mathrm{H}_{2}$ and $\mathrm{CH}_{4}$. The formation of $\mathrm{CO}$ increased with increasing temperature of torrefaction owing to degradation of low molecular weight carbonyl compounds contained in the major components of sugarcane bagasse, while $\mathrm{CO}_{2}$ decreased with increasing torrefaction temperature. The reduction in $\mathrm{CO}_{2}$ as torrefaction reaction temperature increased was mainly attributed to the carboxyl groups in the hemicellulose structure of the material, which becomes unstable as temperature increased. The composition of $\mathrm{H}_{2}$ was maximum at $300^{\circ} \mathrm{C}$ and is attributed to the content of $\mathrm{H}_{2} \mathrm{O}$ formed from the thermal decomposition of sugarcane bagasse. In addition to the freely bound $\mathrm{H}_{2} \mathrm{O}$ that is usually liberated from the biomass through evaporation during thermal treatment, $\mathrm{H}_{2} \mathrm{O}$ is also usually formed as a product of a torrefaction process of biomass [25]. The solid and gaseous products formed during torrefaction of biomass are favourable to the quality of the biomass for thermal conversion processes such as gasification [28]. 


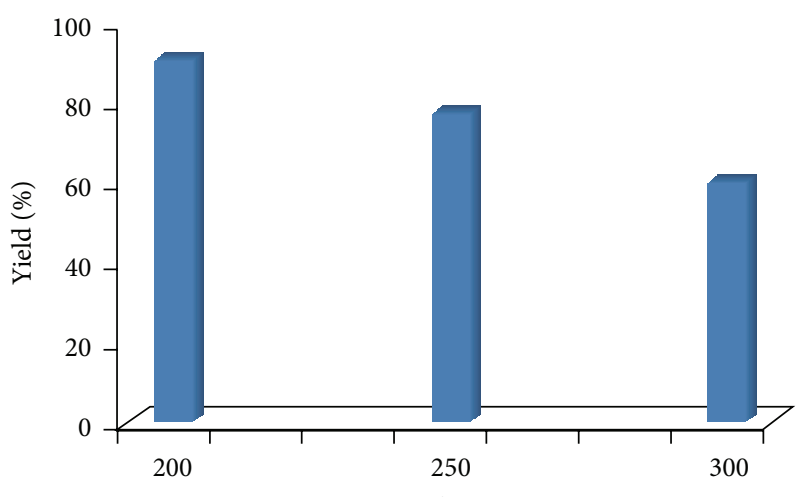

$\left({ }^{\circ} \mathrm{C}\right)$

(a)

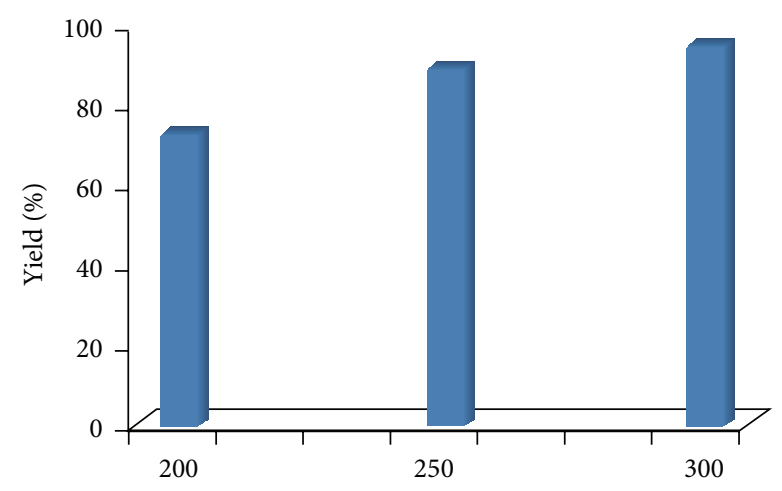

$\left({ }^{\circ} \mathrm{C}\right)$

(b)

FIGURE 2: Input and output parameters obtained from sugarcane bagasse torrefaction at various temperatures: (a) mass yield and (b) energy yield.

3.1.1. Mass and Energy Balances from Sugarcane Bagasse Torrefaction. Typical torrefaction processes are usually characterized by determination of mass and energy balances, most often termed mass and energy yield. The results of the mass and energy yields from sugarcane bagasse torrefied at various temperatures are given in Figures 2(a) and 2(b). The mass yield of a torrefaction process of a biomass material is the ratio of the actual mass retained after torrefaction to the initial mass of the biomass, expressed in weight percentage, while the energy yield provides information on the fraction of the original energy retained in the biomass after torrefaction [6].

It is quite obvious from Figure 2(a) that mass yield decreases as torrefaction temperature increases, a condition attributed to lignin devolatilization caused by increase in the temperature of torrefaction. A mass yield of about 90.6, 77.4, and $60.3 \%$ was obtained at 200,250 , and $300^{\circ} \mathrm{C}$, respectively, which falls within the same range of values obtained for the solid yield formed from bagasse torrefaction at different temperatures previously presented in Figure 1(a). However, the most severe torrefaction condition $\left(300^{\circ} \mathrm{C}\right)$ resulted in the lowest mass yield of about $60 \%$, while the highest mass yield (about 90\%) was observed for the mildest torrefaction condition of $200^{\circ} \mathrm{C}$. On the other hand in Figure 2(b), the
TABle 2: Proximate analysis of sugarcane bagasse at different torrefaction temperatures.

\begin{tabular}{lcccc}
\hline \multirow{2}{*}{ Temperature of torrefaction $\left({ }^{\circ} \mathrm{C}\right)$} & \multicolumn{4}{c}{ Fuel properties $($ wt.\%, db) } \\
& MC & VM & FC & AS \\
\hline 200 & 4.8 & 60.8 & 31.6 & 2.8 \\
250 & 1.74 & 51.7 & 38.2 & 8.4 \\
300 & 0.87 & 48.07 & 34.45 & 16.61 \\
\hline
\end{tabular}

Note: MC: moisture content, VM: volatile matter content, FC: fixed carbon, AS: ash, and db: dry basis.

opposite is the case for the energy yield obtained from the torrefaction of bagasse at different temperatures. Energy yield increased with increasing torrefaction temperature, with the highest yield recorded for the $300^{\circ} \mathrm{C}$. This is again attributed to the loss in energy-lean components of the material. Energy-rich components are usually retained at the expense of the energy-lean components after torrefaction of biomass [29]. The energy densification benefit of a torrefaction process is illustrated by around $70 \%$ mass yield and about $90 \%$ energy yield, respectively [30]. In relation to gasification, however, the mass and energy balance results obtained show that torrefied sugarcane bagasse used in this study would favour high temperature gasification because reduced mass and high energy yields are conditions that are favourable to gasification, and these conditions increase for the gasification process according to the temperature at which the material has been torrefied [6].

3.2. Torrefied Sugarcane Bagasse Characterization. Torrefaction leads to a significant change in the properties of biomass, with most of these changes favourable to the thermal conversion of the material into energy [6]. The following subsections attempt to discuss the modifications of the properties of sugarcane bagasse torrefied at various temperatures through characterization of the material using analytical instruments that are relevant to gasification.

3.2.1. Proximate, Ultimate, and Calorific Value Analyses of Torrefied Sugarcane Bagasse. Data from the proximate, ultimate, and calorific value analyses of sugarcane bagasse torrefied at various temperatures are given in Table 1 . These were determined from the TGA plots in Figure 3 according to the equation parameters presented in Table 2.

From Table 2, it is clear that the contents of moisture and volatile matter of the torrefied material decreased with increasing temperature of torrefaction due to high temperature environment, while fixed carbon increases and then decreased as the torrefaction reaction temperature attains $300^{\circ} \mathrm{C}$. The weight percentage of fixed carbon is determined by those of moisture, volatile matter, and ash contents of a biomass material, so inconsistency in the weight percentages of these properties affects the inconsistency in the weight percentage of fixed carbon [31]. Ash content increased with rising torrefaction temperature, which was owing to mass loss as temperature increased during torrefaction, leading to the build-up of high concentration of metallic elements. High 
TABLE 3: Ultimate and calorific value analyses of bagasse at different torrefaction temperatures.

\begin{tabular}{lccccccc}
\hline \multirow{2}{*}{ Temperature of torrefaction $\left({ }^{\circ} \mathrm{C}\right)$} & \multicolumn{9}{c}{ Chemical elements (wt.\%, dab) } & Calorific value (MJ/kg) \\
& $\mathrm{C}$ & $\mathrm{O}$ & $\mathrm{H}$ & $\mathrm{N}$ & $\mathrm{S}$ & $\mathrm{O}-\mathrm{C}$ & 17.3 \\
200 & 47.6 & 46.1 & 5.4 & 1.9 & 0.03 & 0.9 & 18.8 \\
250 & 54.1 & 41.1 & 4.2 & 0.6 & 0.01 & 0.7 & 20.2 \\
300 & 59.2 & 37.3 & 3.9 & 0.1 & 0.01 & 0.6 & \\
\hline
\end{tabular}

Note: dab: dry-ash-free basis.

ash composition of biomass materials is usually attributed to the high concentration of metallic elements contained in the biomass, and their concentration is equally affected by the thermal treatment of the biomass [6]. Because of the high composition of ash in the torrefied material, some technical challenges ranging from agglomeration, fouling, slagging, and sintering may be experienced during gasification. Ash content of biomass beyond $6 \%$ is undesirable during gasification [32]. However, high ash composition of biomass may sometimes be favourable to gasification because of its catalytic impact as it plays a role in the cracking of high molecular weight compounds formed during gasification and may also change gasification dynamics $[33,34]$. The relative yields and composition of the products generated during gasification are influenced by the proximate analysis properties of the feedstock intended for conversion [35]. High moisture content does not favour gasification as it reduces feedstock heating value and leads to incomplete combustion during gasification; the effectiveness of the gasification system is also reduced; therefore, moisture content around $20 \%$ is preferable for gasification depending on the type of gasifier used as some systems can tolerate as high as 35\% feedstock moisture content [36]. High volatile matter content of biomass implies excessive volatilization during gasification which may contribute to the formation of high amount of tar, soot, and smoke that may also reduce the efficiency of the gasification process, while fixed carbon contributes to char formation, in which case a high amount of fixed carbon would imply increasing char formation $[5,6]$.

Table 3 presents the ultimate and calorific value information of bagasse torrefied at different reaction temperatures.

The chemical make-up of torrefied sugarcane bagasse in Table 3 suggests that the $\mathrm{C}$ content of the material increased with increasing temperature of torrefaction. This is attributed to the formation of $\mathrm{H}_{2} \mathrm{O}, \mathrm{CO}$, and $\mathrm{CO}_{2}$ and the removal of volatiles from the material. However, increasing temperature during torrefaction results in an increase in the $\mathrm{C}$ content of the torrefied material, with a simultaneous reduction in its $\mathrm{H}_{2}$ and $\mathrm{O}_{2}$ contents, respectively; the composition and yield of products during biomass torrefaction are influenced by the temperature of torrefaction as well as the time and properties of the material $[29,37]$. The weight percentage of $\mathrm{O}_{2}$ also decreases as torrefaction temperature increased because of the cracking of highly reactive $\mathrm{O}_{2}$-containing functional groups present in the molecular structure of the torrefied material. During thermal treatment of biomass, the highly reactive $\mathrm{O}_{2}$-containing functional groups in the structure of the biomass require low activation energy in form of heat to be cracked [38]. The decrease in the weight percentage of $\mathrm{H}_{2}$ as torrefaction temperature increased was as a result of the evaporation of moisture from the material and the liberation of hydrocarbons such as $\mathrm{CH}_{4}$ and $\mathrm{C}_{2} \mathrm{H}_{6}$, which occurs only when there is an increase in temperature. $\mathrm{A}$ reduction in the content of $\mathrm{H}_{2}$ during torrefaction of biomass at high temperatures is usually attributed to the release of water and hydrocarbons from the torrefied material [38]. The weight percentages of $\mathrm{N}_{2}$ and $\mathrm{S}$ are extremely low; hence, no significant changes in their concentration can be reported, and therefore, emissions of $\mathrm{NO}_{x}$ and $\mathrm{SO}_{x}$ during gasification of torrefied sugarcane bagasse (SCB) should be negligible. It is also evident from Table 3 that the $\mathrm{O}-\mathrm{C}$ ratio of the torrefied material diminished with increasing temperature of torrefaction. Cellulose and hemicellulose consumption during torrefaction are more prominent compared to the consumption of lignin and this results in the abatement of the $\mathrm{O}-\mathrm{C}$ ratio when the biomass undergoes torrefaction; and the volume and composition of the combustible gases in the product syngas formed from gasification of biomass are determined by the elemental composition of the biomass $[9,39]$. Reduced O-C ratio implies less smoke and water vapour formation as well as minimal energy losses during gasification [40]. The calorific value of the torrefied material also slightly increased with increasing torrefaction temperature. This is attributed to the expulsion of moisture and the increase in the composition of ash at rising temperature as well as the increase in $\mathrm{C}$ content. The reason for the high ash composition of the torrefied material had previously been explained as well as the effect of feedstock high moisture content. However because the measurement of calorific value is mass based, high ash content as a consequence of high mineral matter content reduces feedstock calorific value, since minerals only contribute little energy during biomass combustion [41, 42]. The quality of biomass materials is usually assessed based on their heating value [39].

\subsubsection{Thermal Behavior of Torrefied Sugarcane Bagasse. The} thermograms resulting from the thermal analysis of torrefied sugarcane bagasse (SCB) obtained at various torrefaction reaction temperatures are presented in Figures 3(a) and $3(b)$. They were obtained as a function of temperature and time so as to adequately describe the conditions existing in a gasification process. The positions where weight loss of the material occurred for the different torrefaction reaction temperatures are clearly indicated by the numbered arrows. This analysis is also necessary to establish the parameters that would influence the thermal conversion of the material. 


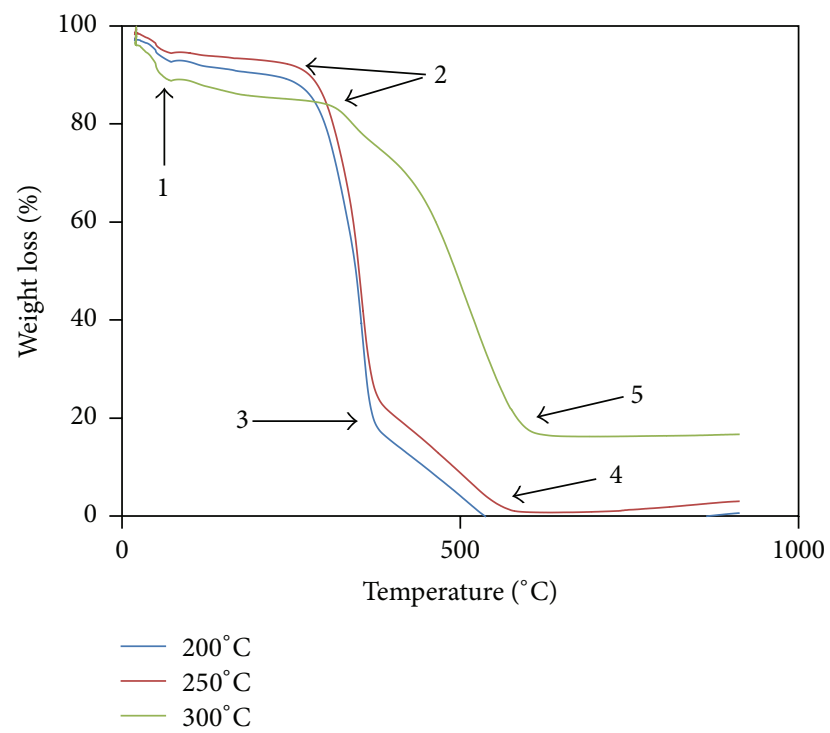

(a)

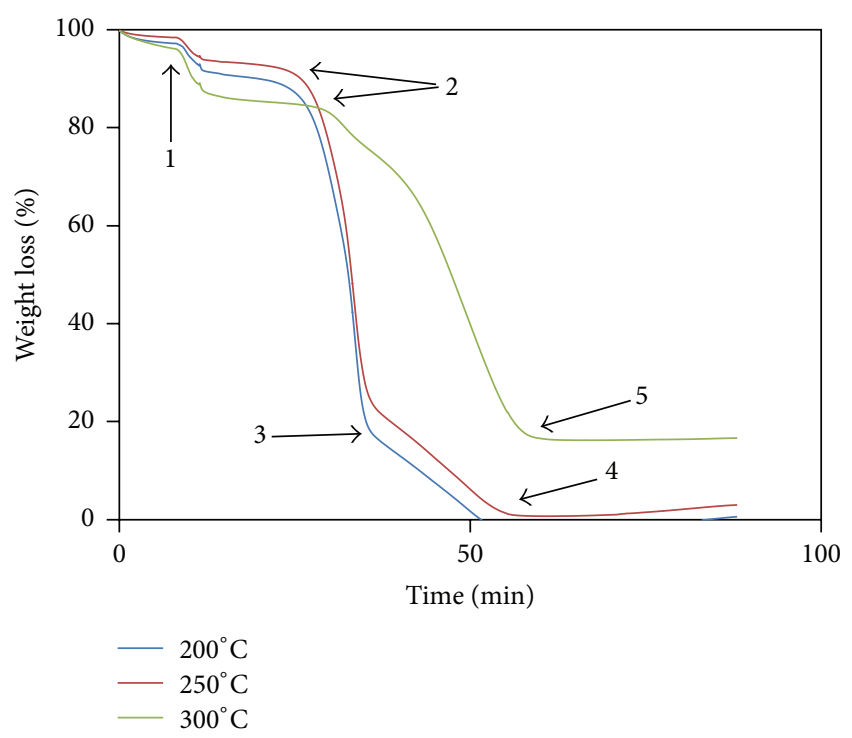

(b)

FIGURE 3: Thermogravimetric profile of torrefied sugarcane bagasse obtained for different torrefaction temperatures with (a) weight loss versus temperature and (b) weight loss versus time.

Weight loss is a valuable measure of the intensity of torrefaction, which is mainly due to thermal deterioration of hemicellulose together with a number of short chain lignin components released in the form of gaseous products such as $\mathrm{CO}, \mathrm{CO}_{2}, \mathrm{H}_{2} \mathrm{O}$, and $\mathrm{CH}_{4}[25,43]$. It can be seen from Figures 3(a) and 3(b) that the thermogravimetric analysis (TGA) plots of SCB torrefied at lower temperatures (200, $250^{\circ} \mathrm{C}$ ) are characterized by four different weight loss stages, whereas that torrefied at $300^{\circ} \mathrm{C}$ showed three distinct weight loss stages. The points where there seems to be reduction in weight are numbered for clarity sake (numbers 1, 2, 3, and 4, for SCB torrefied at 200 and $250^{\circ} \mathrm{C}$, resp., and 1, 2, and 5, for SCB torrefied at $300^{\circ} \mathrm{C}$ ). The time at which reduction in weight occurred for the different torrefaction temperatures is clearly depicted in Figure 3(b), with the stages also distinctly indicated by numbered arrows. The first weight loss stage (Figure 3(a), stage 1) for all torrefaction temperatures occurred at about $90^{\circ} \mathrm{C}$ and can be attributed to further loss of moisture from the torrefied material (some moisture had been lost through torrefaction before TGA analysis). This took ca. $7 \mathrm{~min}$ to occur according to the weight loss versus time profile in Figure 3(b). At this first decomposition temperature stage, the weight of the material was close to about $90 \%$, implying that around $10 \%$ of the weight of the torrefied material had been lost through combustion. However, at the lower temperatures of torrefaction (200 and $250^{\circ} \mathrm{C}$ ), the characteristic shapes of the TGA curves obtained are quite similar, with rapid weight loss occurring at ca. $235^{\circ} \mathrm{C}$ (Figure 3(a), stage 2) and the weight of the material remaining at $85 \%$, suggesting a $15 \%$ loss in weight and occurring after ca. $25 \mathrm{~min}$ of analysis. This sharp drop in weight at the said temperature is owing to excessive devolatilization as a result of hemicellulose degradation, leading to the weight loss in stages 3 and 4, respectively. The weight loss at these stages is still attributed to rapid devolatilization as a consequence of cellulose and lignin decomposition at temperatures above $360^{\circ} \mathrm{C}$ for cellulose and up to $870^{\circ} \mathrm{C}$ for lignin. These are the maximum decomposition temperatures for these components when the material undergoes complete combustion; beyond these temperature ranges, complete decomposition of the material may have occurred $[6,19]$. These decomposition temperatures differ from the reaction temperatures under which torrefaction of sugarcane bagasse was conducted, although parts of the components may have been devolatilized upon the torrefaction reaction temperatures of 200,250 , and $300^{\circ} \mathrm{C}$, leading to reduced mass of the material that implies improved properties of the material because of drying and carbonization [30]. As previously mentioned, however, cellulose, hemicellulose, and lignin are the three major constituents of biomass materials. Because of the underlying differences in the structure of these components, they can be differentiated and identified by the use of TGA $[44,45]$. The decomposition temperature range of cellulose is between 315 and $400^{\circ} \mathrm{C}$, while hemicellulose degradation occurs in the temperature range of 200 to $250^{\circ} \mathrm{C}$; and lignin degrades over a wide temperature range from 160 to $1000^{\circ} \mathrm{C}[19,43]$. In contrast, for SCB torrefied at $300^{\circ} \mathrm{C}$, a swift loss in weight occurred at a much higher temperature of about $350^{\circ} \mathrm{C}$ (Figure 3(a), stage 2 of the torrefied material at $300^{\circ} \mathrm{C}$ ) and represents excessive devolatilization of hemicellulose and cellulose, which occurred due to severity of torrefaction, suggesting that a considerable part of the torrefied material had degraded at the torrefaction reaction temperature of $300^{\circ} \mathrm{C}$ before the material was subjected to thermogravimetric analysis (TGA). This again, according to the time profile in Figure 3(b), took place after about $32 \mathrm{~min}$. At this time, the weight of the material was ca. $80 \%$, implying a $20 \%$ loss in the weight of the material. From this analysis, a $5 \%$ reduction in the weight of the torrefied material could be noticed as torrefaction reaction temperature increased from 200 to $250^{\circ} \mathrm{C}$ and lastly to $300^{\circ} \mathrm{C}$. The third weight loss stage of SCB torrefied at $300^{\circ} \mathrm{C}$ (Figure 3(a), stage 3 ) is attributed to lignin decomposition at temperatures close to $900^{\circ} \mathrm{C}$. At this 
stage, and after $90 \mathrm{~min}$ of analysis, about $83 \%$ of the weight of the material had been lost.

This analysis provided a basis for understanding the gasification behavior of sugarcane bagasse torrefied at different temperatures and establishes that, depending on the temperature at which the material had been torrefied before gasification and irrespective of the weight loss that the torrefied material would experience during gasification, a number of short and long chain light weight organic compounds would be released as a consequence of the composition of the torrefied material. However, the liberation of these compounds would, no doubt, depend on the gasification conditions, which will include temperature [11].

3.3. Surface Morphology and Elemental Analysis. The scanning electron micrographs (SEM) obtained for sugarcane bagasse torrefied at 200,250 , and $300^{\circ} \mathrm{C}$ are presented in Figures 4(a), 4(b), and 4(c), respectively. Their respective EDX spectrums are also presented side by side with the SEM images to serve as a comparative analysis to the ultimate analysis data presented in Table 3. These analyses are necessary to comprehend the impact of torrefaction reaction temperature on the structure as well as on the elemental composition of the torrefied material and how these would influence the gasification process of the material.

The morphological images in Figure 4 show typical irregular shapes of particles of sugarcane bagasse torrefied at various temperatures. The difference on the surface of the images is quite evident and the main distinct features are those of particle size which becomes smaller and dispersed at increased torrefaction temperature, with tiny particles consumed at higher torrefaction temperatures $\left(250\right.$ and $\left.300^{\circ} \mathrm{C}\right)$. When torrefaction temperature is increased, the effect of thermal pretreatment of the biomass is enhanced and smaller particles are destroyed, resulting in tiny pores and tubular structures [9]. As evident in Figure 4(a), for torrefaction temperature of $200^{\circ} \mathrm{C}$, a deformation of the fibrous structure (which sugarcane bagasse is known for) becomes noticeable and fizzles away, forming tiny dispersed particles as torrefaction temperature increases. This is particularly evident in Figure 4(b) (for torrefaction temperature of $250^{\circ} \mathrm{C}$ ). On the contrary, at higher torrefaction temperature of $300^{\circ} \mathrm{C}$, the tiny dispersed particles fuse together, forming a tubular structure attributed to agglomerates of $\mathrm{Si}$ and $\mathrm{P}$ as a consequence of lignin degradation. Lignin has been reported as a binding agent that acts as a glue to bind plant cells together [46]. This is basically the reason why the fibrous nature of sugarcane bagasse was lost after torrefaction. The reason why biomass materials lose their fibrous structure and become easily grindable with less consumption of energy after torrefaction is due to the cementing nature of lignin [46]. It can also be noted from Figure 4(c) (for torrefaction reaction temperature of $300^{\circ} \mathrm{C}$ ) that cell structures are clearly deformed as a result of cellulose degradation. Size reduction of biomass becomes energy intensive and a cost effective process as a result of the tenacious fibrous nature of the biomass; the breaking down of the cell and fibrous structures promotes high gasification reactivity [47]. Important parameters used to understand the combustion behavior of biomass materials with a conventional feedstock such as coal during gasification include the distribution of particle size and surface area as well as sphericity [48].

The EDX spectrums of sugarcane bagasse torrefied at various temperatures presented in Figures $4\left(a_{1}\right), 4\left(b_{1}\right)$, and $4\left(c_{1}\right)$ also suggest that $\mathrm{C}$ and $\mathrm{O}_{2}$ are the main elemental constituents of the torrefied material. This is consistent with the ultimate analysis data presented in Section 3.2.1. The fate of these elements in relation to increasing torrefaction temperature and gasification had been previously discussed. However, in addition to the ultimate analysis data previously presented, the EDX results show that the torrefied material also contains $\mathrm{Al}, \mathrm{Ca}, \mathrm{K}, \mathrm{Mg}, \mathrm{Na}$, and $\mathrm{Si}$ including $\mathrm{Fe}, \mathrm{P}$, and $\mathrm{S}$ in varying proportions. The concentration of these elements rises with increasing torrefaction temperature due to excessive devolatilization and carbonization as a result of lignin decomposition at higher temperatures. These elements are nonvolatile under any conditions of torrefaction and form the basis of the catalytically active mineral components of the torrefied material; they are important parameters that determine char reactivity during gasification because char reactivity increases with increasing concentration of the inorganic constituents of the biomass $[49,50]$. However, the major ash-forming element in biomass is Si [51] and its concentration increases with increasing torrefaction temperature as evident in Figure $4\left(c_{1}\right)$. This is most probably the reason why high ash composition was recorded for sugarcane bagasse torrefied at $300^{\circ} \mathrm{C}$ (presented in Table 1 , Section 3.2.1). High Si concentration inhibits reactivity and gasification of biomass [52]. Quite an appreciable amount of $\mathrm{P}$ was also detected for sugarcane bagasse torrefied at $300^{\circ} \mathrm{C}$ because of the reasons previously adduced. $\mathrm{P}$ may behave in a similar way as $\mathrm{Si}$; hence it would be relevant to take into cognizance the ratio of $\mathrm{Si}-\mathrm{P}$ in the torrefied material during gasification because considering the proximity in the electronic configuration of the cations of $\mathrm{P}$ and $\mathrm{Si}$ (given as $\mathrm{P}^{5+}$ and $\mathrm{Si}^{4+}$ ), both elements are assumed to have the same inhibitory impact on the reactivity of char during gasification $[52,53]$. Other ash-forming elements as detected by EDX that could also be the reason for the high ash content reported for sugarcane bagasse torrefied at $300^{\circ} \mathrm{C}$ include $\mathrm{Al}, \mathrm{Ca}, \mathrm{Fe}, \mathrm{K}$, $\mathrm{Na}$, and $\mathrm{Mg}$ [54]. During combustion or gasification, these metal elements are present in ash in their oxide forms such as $\mathrm{Al}_{2} \mathrm{O}_{3}, \mathrm{CaO}, \mathrm{Fe}_{2} \mathrm{O}_{3}, \mathrm{~K}_{2} \mathrm{O}$, and $\mathrm{Na}_{2} \mathrm{O}$ including $\mathrm{MgO}$, and their catalytic effect during gasification is encapsulated by the presence of Si and P $[53,54]$. The SEM images of sugarcane bagasse torrefied at various temperatures presented in Figures 4(a), 4(b), and 4(c) confirmed the inhibiting effects of Si and $\mathrm{P}$ via agglomerates formation.

The blue marker lines in the spectra of Figures $4\left(a_{1}\right)$, $4\left(b_{1}\right)$, and $4\left(c_{1}\right)$ are lines from the instrument that interfered with the spectra during analysis; they have no apparent meaning and were therefore disregarded in the course of interpretation of the data obtained from the SEM/EDX analysis.

\section{Conclusions}

The impact of torrefaction process conditions on the physicochemical characteristics as well as on mass and energy yields 


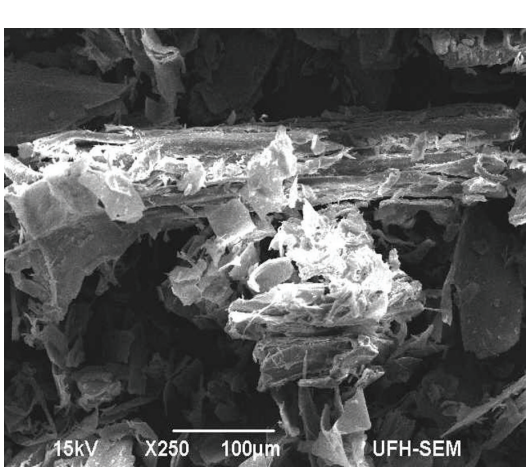

(a) $200^{\circ} \mathrm{C}$

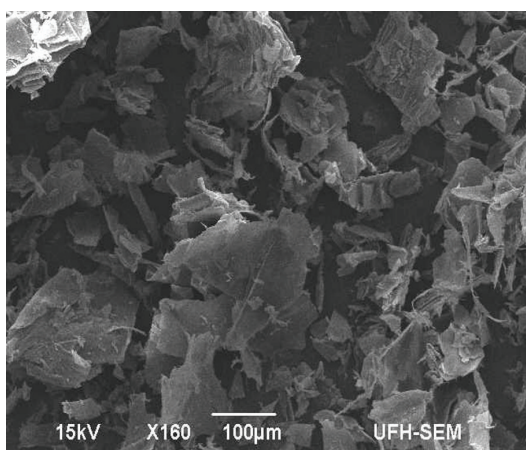

(b) $250^{\circ} \mathrm{C}$

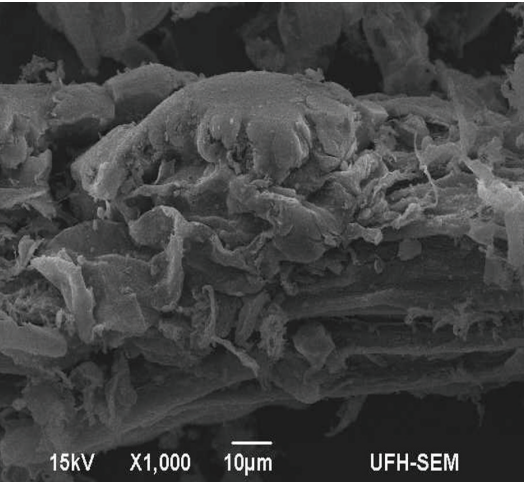

(c) $300^{\circ} \mathrm{C}$

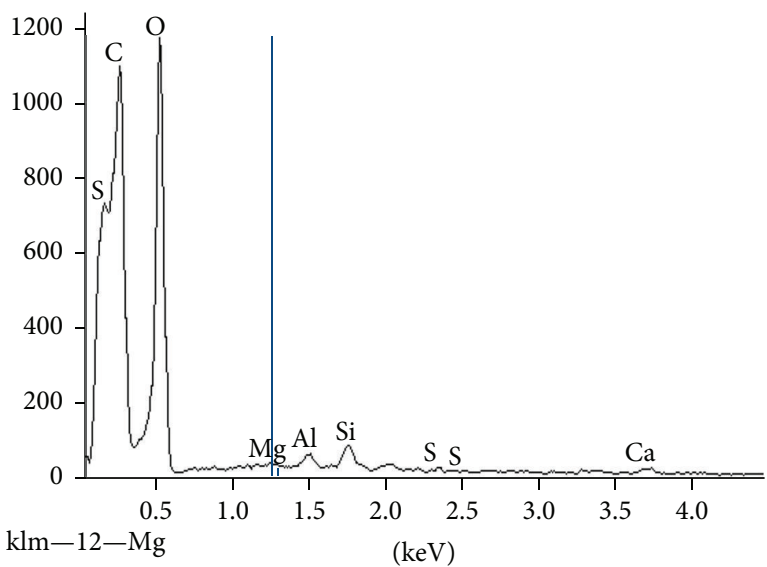

$\left(a_{1}\right) 200^{\circ} \mathrm{C}$

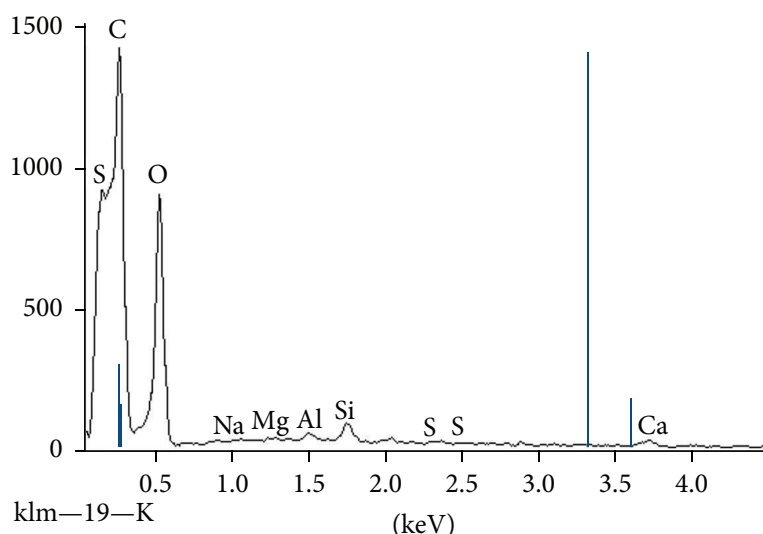

$\left(\mathrm{b}_{1}\right) 250^{\circ} \mathrm{C}$

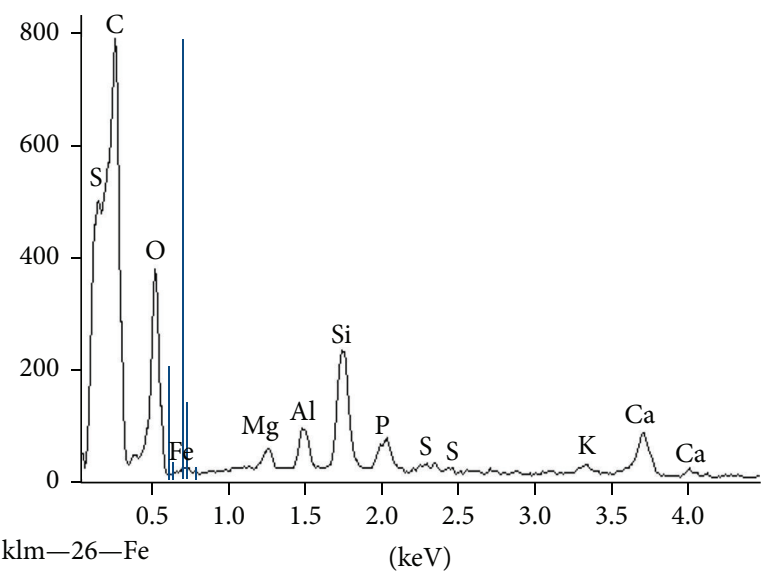

$\left(c_{1}\right) 300^{\circ} \mathrm{C}$

FIGURE 4: SEM images of sugarcane bagasse torrefied at different temperatures and their respective EDX spectrums with torrefaction for (a) $200^{\circ} \mathrm{C}$, (b) $250^{\circ} \mathrm{C}$, and (c) $300^{\circ} \mathrm{C}$.

was examined by varying torrefaction reaction temperature and the relevance of these changes in characteristics to gasification established. The results show that reaction temperature has significant influence on the physical, chemical, and morphological characteristics of torrefied sugarcane bagasse. Increasing torrefaction reaction temperature led to a reduction in the yield of the solid product with subsequent increases in the yield of liquid and gaseous products as well as significant decreases in moisture and volatile matter contents, respectively. A significant increase in the content of ash as torrefaction temperature increased was also reported, which was due to the increased content of inorganic elements of the torrefied material as a consequence of excessive material devolatilization. Calorific value also increased with torrefaction temperature due to reduced moisture and $\mathrm{O}_{2}$ contents as well as increased C content. However, there was a reduction 
in the $\mathrm{O}-\mathrm{C}$ ratio as torrefaction temperature increased owing to the partial consumption of elemental $\mathrm{O}_{2}$. Mass yield also decreased with increasing torrefaction temperature as a result of the decomposition of reactive hemicellulose fraction of the torrefied material, with consequent increase in energy yield. The TGA results obtained for sugarcane bagasse torrefied at different temperatures are in good agreement with the performance of the material in a typical gasification system and suggest that temperature ranges, heating rates, and gaseous environment are among the parameters relevant to the conditions existing in a gasification system. The fibrous structure which sugarcane bagasse is known for becomes lost upon torrefaction, with cracks and fissures becoming more evident at higher torrefaction temperatures, especially with the sample torrefied at $300^{\circ} \mathrm{C}$, as revealed by SEM observation which also confirmed the same inhibiting effects of Si and P.

From gasification standpoint, the higher the temperature of torrefaction, the better the yield of syngas as high syngas yield translates into increased gasification efficiency. Therefore, the characteristics of torrefied sugarcane bagasse discussed above enhance its application as a feedstock for gasification purposes. The reactivity of sugarcane bagasse torrefied at different temperatures and its influence on the hydrophobic properties of the material as well as on the gasification process deserve further research including the influence of torrefaction reaction time on the physical and chemical properties of sugarcane bagasse and on the mass and energy yields of the torrefaction process. The impact of these on the gasification process of sugarcane bagasse is also worthy of further study, and the simultaneous consideration of capital and operating costs for torrefaction and gasification of bagasse together with optimization of torrefaction process conditions in order to establish the economic viability of the processes (torrefaction and gasification). Further research is also required on the gasification of sugarcane bagasse torrefied at various temperatures in order to establish the influence of changes in properties of bagasse on the conversion efficiency of its gasification process under standard and various gasifier operating conditions.

\section{Conflict of Interests}

The authors declare no conflict of interests regarding the publication of this research paper.

\section{Acknowledgments}

The authors gratefully acknowledge the financial support of the National Research Foundation of South Africa and the Sasol Inzalo Foundation as well as the Govan Mbeki Research and Development Center of the University of Fort Hare. The technical assistance of the Fort Hare Institute of Technology and that of the Chemistry Department of the University of Fort Hare are also gratefully acknowledged.

\section{References}

[1] B. Arias, C. Pevida, J. Fermoso, M. G. Plaza, F. Rubiera, and J. J. Pis, "Influence of torrefaction on the grindability and reactivity of woody biomass," Fuel Processing Technology, vol. 89, no. 2, pp. $169-175,2008$.

[2] N. L. Panwar, R. Kothari, and V. V. Tyagi, "Thermo chemical conversion of biomass-eco friendly energy routes," Renewable and Sustainable Energy Reviews, vol. 16, no. 4, pp. 1801-1816, 2012.

[3] B. M. Jenkins, L. L. Baxter, T. R. Miles Jr., and T. R. Miles, "Combustion properties of biomass," Fuel Processing Technology, vol. 54, no. 1-3, pp. 17-46, 1998.

[4] M. J. C. van der Stelt, H. Gerhauser, J. H. A. Kiel, and K. J. Ptasinski, "Biomass upgrading by torrefaction for the production of biofuels: a review," Biomass \& Bioenergy, vol. 35, no. 9, pp. 3748-3762, 2011.

[5] A. Saddawi, J. M. Jones, A. Williams, and C. Le Coeur, "Commodity fuels from biomass through pretreatment and torrefaction: effects of mineral content on torrefied fuel characteristics and quality," Energy \& Fuels, vol. 26, no. 11, pp. 64666474, 2012.

[6] G. Xue, M. Kwapinska, W. Kwapinski, K. M. Czajka, J. Kennedy, and J. J. Leahy, "Impact of torrefaction on properties of Miscanthus $\times$ giganteus relevant to gasification," Fuel, vol. 121, pp. 189197, 2014.

[7] R. Pentananunt, A. N. M. M. Rahman, and S. C. Bhattacharya, "Upgrading of biomass by means of torrefaction," Energy, vol. 15, no. 12, pp. 1175-1179, 1990.

[8] D. Medic, M. Darr, A. Shah, B. Potter, and J. Zimmerman, "Effects of torrefaction process parameters on biomass feedstock upgrading," Fuel, vol. 91, no. 1, pp. 147-154, 2012.

[9] W.-H. Chen, W.-Y. Cheng, K.-M. Lu, and Y.-P. Huang, "An evaluation on improvement of pulverized biomass property for solid fuel through torrefaction," Applied Energy, vol. 88, no. 11, pp. 3636-3644, 2011.

[10] L. Khezami, A. Chetouani, B. Taouk, and R. Capart, "Production and characterisation of activated carbon from wood components in powder: cellulose, lignin, xylan," Powder Technology, vol. 157, no. 1-3, pp. 48-56, 2005.

[11] K. G. Mansaray and A. E. Ghaly, "Thermal degradation of rice husks in nitrogen atmosphere," Bioresource Technology, vol. 65, no. 1-2, pp. 13-20, 1998.

[12] X. T. Bi and X. Liu, "High density and high solids flux CFB risers for steam gasification of solids fuels," Fuel Processing Technology, vol. 91, no. 8, pp. 915-920, 2010.

[13] S. Chang, Z. Zhao, A. Zheng, F. He, Z. Huang, and H. Li, "Characterization of products from torrefaction of sprucewood and bagasse in an auger reactor," Energy and Fuels, vol. 26, no. 11, pp. 7009-7017, 2012.

[14] L. E. Taba, M. F. Irfan, W. A. M. Wan Daud, and M. H. Chakrabarti, "The effect of temperature on various parameters in coal, biomass and CO-gasification: a review," Renewable and Sustainable Energy Reviews, vol. 16, no. 8, pp. 5584-5596, 2012.

[15] B. Buragohain, P. Mahanta, and V. S. Moholkar, "Biomass gasification for decentralized power generation: the Indian perspective," Renewable \& Sustainable Energy Reviews, vol. 14, no. 1, pp. 73-92, 2010.

[16] C. Gai and Y. Dong, "Experimental study on non-woody biomass gasification in a downdraft gasifier," International Journal of Hydrogen Energy, vol. 37, no. 6, pp. 4935-4944, 2012.

[17] A. Kumar, D. D. Jones, and M. A. Hanna, "Thermochemical biomass gasification: a review of the current status of the technology," Energies, vol. 2, no. 3, pp. 556-581, 2009. 
[18] T. G. Bridgeman, J. M. Jones, I. Shield, and P. T. Williams, "Torrefaction of reed canary grass, wheat straw and willow to enhance solid fuel qualities and combustion properties," Fuel, vol. 87, no. 6, pp. 844-856, 2008.

[19] J. Deng, G.-J. Wang, J.-H. Kuang, Y.-L. Zhang, and Y.-H. Luo, "Pretreatment of agricultural residues for co-gasification via torrefaction," Journal of Analytical \& Applied Pyrolysis, vol. 86, no. 2, pp. 331-337, 2009.

[20] A. Pimchuai, A. Dutta, and P. Basu, "Torrefaction of agriculture residue to enhance combustible properties," Energy \& Fuels, vol. 24, no. 9, pp. 4638-4645, 2010.

[21] LECO Corporation, "Moisture, volatile matter, ash, and fixed carbon determination-Solid fuel characterization measurements in coke," Organic Application Note, Form 203821-381, LECO Corporation, St. Joseph, Mich, USA, 2010, http:// www.leco.co.za/wp-content/uploads/2012/02/TGA701_COKE_ 203-821-381.pdf.

[22] P. C. A. Bergman, A. R. Boersma, J. H. A. Kiel, M. J. Prins, K. J. Ptasinski, and F. G. G. J. Janssen, "Torrefied biomass for entrained-flow gasification of biomass," Tech. Rep. ECN-C-05026, Energy Research Centre of the Netherlands (ECN), Petten, The Netherlands, 2005.

[23] W.-H. Chen, H.-C. Hsu, K.-M. Lu, W.-J. Lee, and T.-C. Lin, "Thermal pretreatment of wood (Lauan) block by torrefaction and its influence on the properties of the biomass," Energy, vol. 36, no. 5, pp. 3012-3021, 2011.

[24] W.-H. Chen, K.-M. Lu, W.-J. Lee, S.-H. Liu, and T.-C. Lin, "Nonoxidative and oxidative torrefaction characterization and SEM observations of fibrous and ligneous biomass," Applied Energy, vol. 114, pp. 104-113, 2014.

[25] P. C. A. Bergman, A. R. Boersman, R. W. R. Zwart, and J. H. A. Kiel, Torrefaction for biomass co-firing in existing coalfired power stations. "BIOCOAL", Renewable Energy in the Netherlands 2005.

[26] C. Couhert, S. Salvador, and J.-M. Commandré, "Impact of torrefaction on syngas production from wood," Fuel, vol. 88, no. 11, pp. 2286-2290, 2009.

[27] X. Luo, Torrefaction of biomass - a comparative and kinetic study of thermal decomposition for Norway spruce stump, poplar and fuel tree chips [M.S. thesis], Swedish University of Agricultural Sciences, Uppsala, Sweden, 2011.

[28] M. Wilk, A. Magdziarz, and I. Kalemba, "Characterisation of renewable fuels' torrefaction process with different instrumental techniques," Energy, vol. 87, pp. 259-269, 2015.

[29] M. Dorde, Investigation of torrefaction process parameters and characterization of torrefied biomass [Ph.D. thesis], Iowa State University, Ames, Iowa, USA, 2012.

[30] P. C. A. Bergman, A. R. Boersma, J. H. A. Kiel, M. J. Prins, K. J. Ptasinski, and F. J. J. G. Janssen, "Torrefied biomass for entrained-flow gasification of biomass," Tech. Rep. ECN-C05-026, Energy Research Centre of the Netherlands (ECN), Petten, The Netherlands, 2005, http://www.ecn.nl/docs/library/ report/2005/c05067.

[31] J. A. Pazó, E. Granada, Á. Saavedra, P. Eguía, and J. Collazo, "Biomass thermogravimetric analysis: uncertainty determination methodology and sampling maps generation," International Journal of Molecular Sciences, vol. 11, no. 7, pp. 2701-2714, 2010.

[32] B. Hahn, Existing Guidelines and Quality Assurance for Fuel Pellets-Pellets for Europe Project, UMBERA Umweltorientierte Betriebsberatungs-, Forschungs- und Entsorgungs-Gesellschaft m.b.H., 2004.
[33] R. Fahmi, A. V. Bridgwater, I. Donnison, N. Yates, and J. M. Jones, "The effect of lignin and inorganic species in biomass on pyrolysis oil yields, quality and stability," Fuel, vol. 87, no. 7, pp. 1230-1240, 2008.

[34] R. Fahmi, A. V. Bridgwater, L. I. Darvell et al., "The effect of alkali metals on combustion and pyrolysis of Lolium and Festuca grasses, switchgrass and willow," Fuel, vol. 86, no. 10-11, pp. 1560-1569, 2007.

[35] J. S. Brar, K. Singh, J. Wang, and S. Kumar, "Cogasification of coal and biomass: a review," International Journal of Forestry Research, vol. 2012, Article ID 363058, 10 pages, 2012.

[36] A. V. Bridgwater, A. J. Toft, and J. G. Brammer, "A technoeconomic comparison of power production by biomass fast pyrolysis with gasification and combustion," Renewable and Sustainable Energy Reviews, vol. 6, no. 3, pp. 181-246, 2002.

[37] J. S. Tumuluru, R. D. Boardman, C. T. Wright, and J. R. Hess, "Some chemical compositional changes in miscanthus and white oak sawdust samples during torrefaction," Energies, vol. 5, no. 10, pp. 3928-3947, 2012.

[38] A. Demirbaş, "Mechanisms of liquefaction and pyrolysis reactions of biomass," Energy Conversion and Management, vol. 41, no. 6, pp. 633-646, 2000.

[39] P. Tanger, J. L. Field, C. E. Jahn, M. W. DeFoort, and J. E. Leach, "Biomass for thermochemical conversion: targets and challenges," Frontiers in Plant Science, vol. 4, article 218, 2013.

[40] J. S. Tumuluru, S. Sokhansanj, C. T. Wright, R. D. Boardman, and R. J. Hess, "Review on biomass torrefaction process and product properties and design of moving bed torrefaction system model development," in Presented at the Annual International Meeting of the American Society of Agricultural and Biological Engineers (ASABE '11), Louiseville, Canada, 2011.

[41] B. M. Jenkins, R. R. Bakker, and J. B. Wei, "On the properties of washed straw," Biomass and Bioenergy, vol. 10, no. 4, pp. 177200, 1996.

[42] C. Sheng and J. L. T. Azevedo, "Estimating the higher heating value of biomass fuels from basic analysis data, Biomass \& Bioenergy, vol. 28, no. 5, pp. 499-507, 2005.

[43] H. Yang, R. Yan, H. Chen, D. H. Lee, and C. Zheng, "Characteristics of hemicellulose, cellulose and lignin pyrolysis," Fuel, vol. 86, no. 12-13, pp. 1781-1788, 2007.

[44] W.-H. Chen and P.-C. Kuo, "A study on torrefaction of various biomass materials and its impact on lignocellulosic structure simulated by a thermogravimetry," Energy, vol. 35, no. 6, pp. 2580-2586, 2010.

[45] W.-H. Chen and P.-C. Kuo, "Torrefaction and co-torrefaction characterization of hemicellulose, cellulose and lignin as well as torrefaction of some basic constituents in biomass," Energy, vol. 36, no. 2, pp. 803-811, 2011.

[46] M. J. Prins, Thermodynamic Analysis of Biomass Gasification and Torrefaction, Technische Universiteit Eindhoven, Eindhoven, The Netherlands, 2005.

[47] B. Arias, C. Pevida, J. Fermoso, M. G. Plaza, F. Rubiera, and J. J. Pis, "Influence of torrefaction on the grindability and reactivity of woody biomass," Fuel Processing Technology, vol. 89, no. 2, pp. $169-175,2008$.

[48] N. Tancredi, T. Cordero, J. Rodríguez-Mirasol, and J. J. Rodríguez, " $\mathrm{CO}_{2}$ gasification of eucalyptus wood chars," Fuel, vol. 75 , no. 13, pp. 1505-1508, 1996.

[49] M. Strandberg, I. Olofsson, L. Pommer, S. Wiklund-Lindström, K. Åberg, and A. Nordin, "Effects of temperature and residence time on continuous torrefaction of spruce wood," Fuel Processing Technology, vol. 134, pp. 387-398, 2015. 
[50] C. Dupont, T. Nocquet, J. A. Da Costa, and C. Verne-Tournon, "Kinetic modelling of steam gasification of various woody biomass chars: influence of inorganic elements," Bioresource Technology, vol. 102, no. 20, pp. 9743-9748, 2011.

[51] E. Gustafsson, Characterization of particulate matter from atmospheric fluidized bed biomass gasifiers [Ph.D. thesis], School of Engineering, Linnaeus University, Kalmar, Sweden, 2011.

[52] G. Urbain, F. Cambier, M. Deletter, and M. R. Anseau, "Viscosity of silicate melts," Transactions and Journal of the British Ceramic Society, vol. 80, pp. 139-141, 1981.

[53] C. Hognon, C. Dupont, M. Grateau, and F. Delrue, "Comparison of steam gasification reactivity of algal and lignocellulosic biomass: influence of inorganic elements," Bioresource Technology, vol. 164, pp. 347-353, 2014.

[54] A. A. Tortosa Masiá, B. J. P. Buhre, R. P. Gupta, and T. F. Wall, "Characterising ash of biomass and waste," Fuel Processing Technology, vol. 88, no. 11-12, pp. 1071-1081, 2007. 

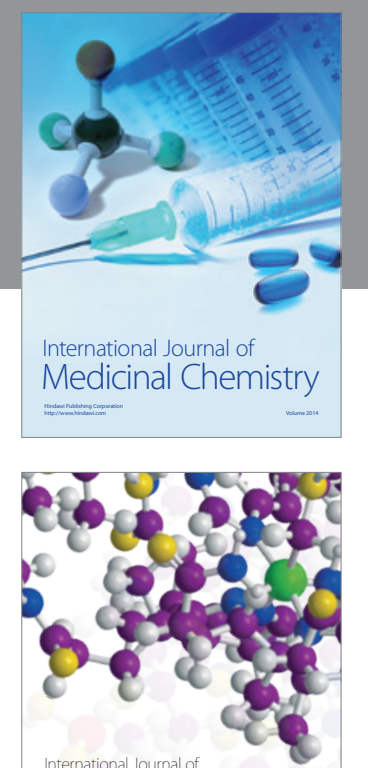

\section{Carbohydrate} Chemistry

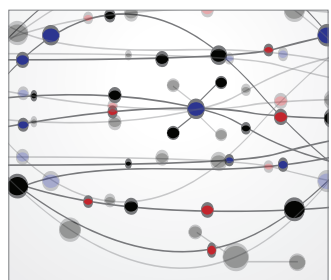

The Scientific World Journal
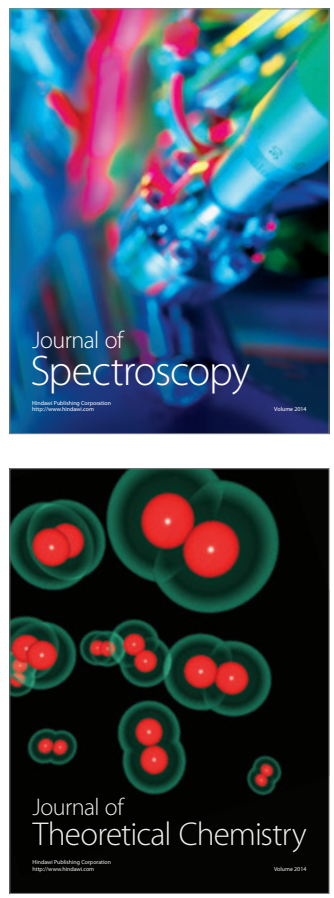
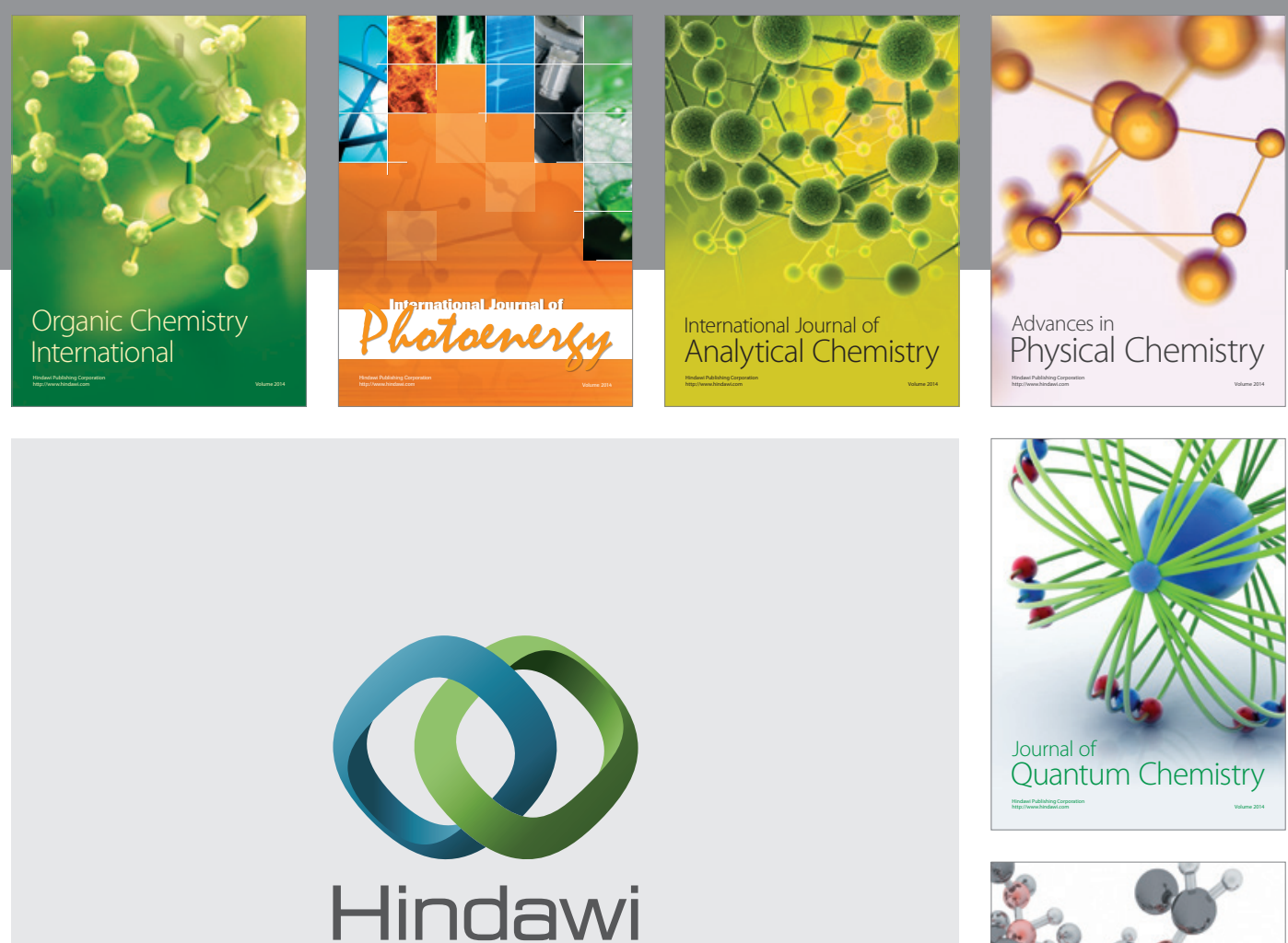

Submit your manuscripts at

http://www.hindawi.com

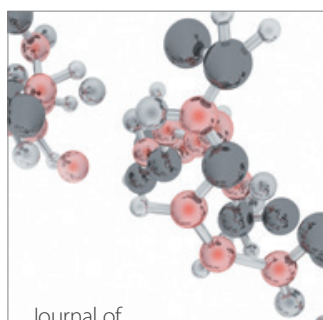

Analytical Methods

in Chemistry

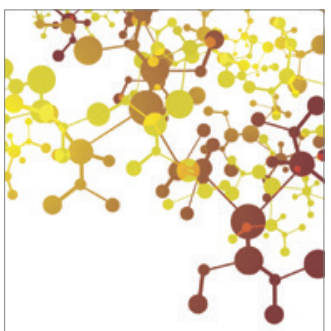

Journal of

Applied Chemistry

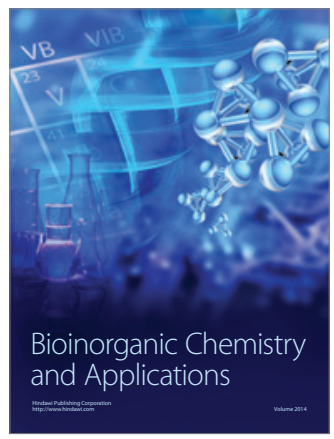

Inorganic Chemistry
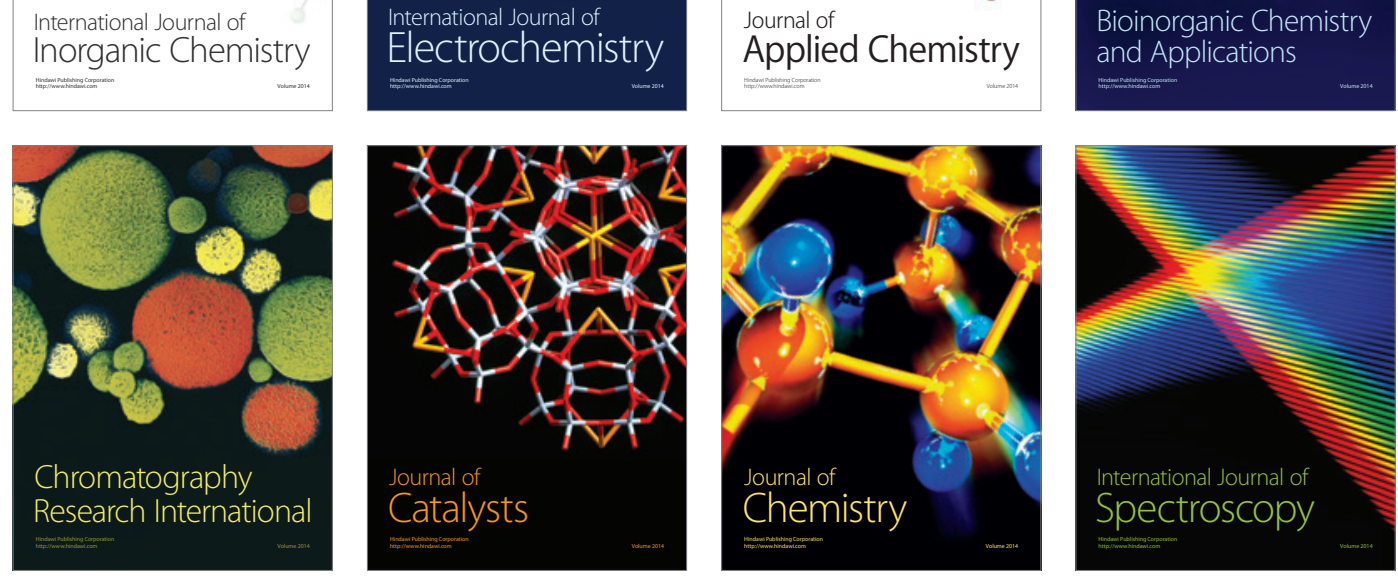